УДК 811.111: 811. 161.2-115

https://doi.org/10.31548/philolog2020.04.040

\title{
OXYMORONIC IMPLICATURES INFERRING IN THE ENGLISH AND UKRAINIAN LANGUAGES
}

\author{
M. G. GOLTSOVA, PhD in Philology, Associate Professor, \\ National University of Life and Environmental Sciences of Ukraine \\ E-mail:mariam88@ukr.net \\ https://orcid.org/ 0000-0003-2385-436X
}

\begin{abstract}
This article deals with oxymoronic implicatures inferring in the English and Ukrainian languages from the logical, pragmatic and comparative aspects. Implicature is a key pragmatic element in the process of communication that shows the differences between what is said from what is meant. Oxymoronic constructions are a conscious combination of sharply contrasting words, that but in fact together they convey a new concept. Oxymoronic implicature is the essence of an indirect statement, in which two or more semantically incompatible concepts are combined, creating a new contradictory thought.

The methods of formal logics and model creating are used in order to infer oxymoronic implicatures. The logical operations of implication, negation and conjunction have been applied to infer implicatures from oxymorons in the English and Ukrainian languages. The logical and pragmatic model of oxymoronic implicatures can be modeled as conjunction of the antecedent $A$ with the negation of the antecedent $\sim A$ from which we could get the implicit result or the value of the consequent $B:(A \& \sim A) \rightarrow B$. A logical and pragmatic algorithm for oxymoronic implicature inferring which consists of five steps has been elaborated.
\end{abstract}

Keywords: implicature, oxymoronic implicature, logical and pragmatic model, logical implication, conjunction, negation, logical and pragmatic model, implicature inferring.

Introduction. One of the fastest-growing areas in linguistics is pragmatics. A key question in pragmatics research is the procedure of inferring implicatures. Implicature is a vital pragmatic element in the process of communication which bridges the gap between what is literally said and what is intentionally meant. The logical character of implicatures means that implicature presupposes the information based on logical laws as well as the language capability and encyclopedic knowledge of the interpreter [3, p. 39].

Oxymoron as a linguistic phenomenon has been known since antiquity: considerations about the role, purpose, sources and causes of its occurrence are found even in the works of ancient Greek and Roman philosophers. In ancient poetics, an oxymoron is a means of creating novelty based on paradoxical poetic thinking, deviation from the norm, an anomaly that makes it possible to distinguish a certain phenomenon from others, convey an idea more accurately, depict eloquently the polar essence of objects and phenomena of objective reality, to impart imagery, emotionality, expressiveness to the language.

An idiosyncrasy of oxymoron is a combination of words contrasting and opposite in their meaning, resulting in a new semantic quality, an unexpected expressive effect, a new concept, e.g.: pain for pleasure, clearly confused, only choice, amazingly awful, alone together, cruel kindness, крижана посмішка, депресивна веселість, запеклі друзі, вперед, до милулого.

In this article we are going to create a logical and pragmatic algorithm aimed at eliciting oxymoronic implicatures.

Recent research and publications. Implicature has been the object of numerous linguistic investigations in recent years. Jessica Rett in her research article Manner implicatures and how to spot them develops a general picture of conversational implicature by looking beyond scalar implicature to see how the phenomenon behaves in a general sense [5]. Michael Franke, Leon Bergen explored grammatically generated implicature readings [2]. Nataliia Kravchenko analysed illocution of direct speech acts via conventional implicature and semantic presupposition [4]. Marianna Goltsova develops a logic and pragmatic algorithm for the inferring euphemistic implicatures and develops a typology of the implicatures in the English and Ukrainian languages [3].

The purpose of this research is to build a logic and pragmatic algorithm with the aim of inferring oxymoronic implicatures in the 
Ukrainian and English languages.

To reach the objective of the research and to accomplish its tasks, a number of general scientific methods (induction, deduction, introspection, analysis) are used. Scientific method of model creating is applied in order to build logic and pragmatic model of implicature. Methods of formal logics helped to infer oxymoronic implicatures. The method of contrastive analysis is applied to reveal the unique and similar features of contrasted languages. Logical and pragmatic model is chosen as the basis for comparison or tertium comparationis.

Results. In our article we will try to decode the intentional meaning of the stylistic device of oxymoron with the help of the logical operations of implication, negation and conjunction, thus combining logical and pragmatic approaches to implicature.

Oxymoron is a figure of speech pairing two words together that are opposing or contradictory. Oxymoron characterizes complexity, internal contradictory of a person, an object or a concept, thus enhancing it, for example: only choice; silent scream; black light; сміх крізь сльози; без надії сподівайся; і мокре горіло; поспішай повільно; початок кіния, неможливе можливо тощо.

Hence, oxymoron is the means of creating semantic contrast based on opposition and juxtaposition of meanings, stylistic parameters of lexical units within one sentence or word combination.

Oxymoron could be seen in Ukrainian and English proverbs and sayings, for example: $\mathrm{Ha}$ льоду гріється, Забажав печеної криги, Де всі крадуть, там немає злодіїв, Зимою сонце крізь плач сміється, Спиш, спиш, а відпочити ніколи, Приймай мале за велике; The only consistency is inconsistency; Please all, and you will please none; Silence is the most powerful scream; Commend a wedded life, but keep thyself a bachelor; Deaf people sometimes hear quickly.

In order to explicate the implicit meaning of the oxymoron we are to delineate the notion of oxymoronic implicature.

Oxymoronic implicature is the essence of an indirect statement, in which two or more diametrically opposed, semantically incompatible concepts are combined; out of them a new, complex, to some extent contradictory thought being developed, which by its meaning occupies a middle place in a verbal phrase.

In order to decode oxymoronic implicatures in this study, we use formal-logical methods. Based on the truth tables for implication, conjunction, negation, we will make an interpretation of the probable intentional content of a statement.

The concept of logical implication is associated with an operation on two logical values, typically the values of two propositions, that produces a value of false just in case the first operand is true and the second operand is false $[1$, p. 25]. In the interpretation where $0=$ false and $1=$ true, the truth table associated with the statement "A implies B", symbolized as $A \rightarrow B$, is as follows:

Table 1. Logical implication

\begin{tabular}{|c|c|c|}
\hline$A$ & $B$ & $A \rightarrow B$ \\
\hline 1 & 1 & 1 \\
\hline 1 & 0 & 0 \\
\hline 0 & 1 & 1 \\
\hline 0 & 0 & 1 \\
\hline
\end{tabular}

Logical conjunction is an operation on two logical propositions that produces a value of true if and only if both of its operands are true [1, p. 25]:

Table 2. Logical conjunction

\begin{tabular}{|l|l|l|}
\hline$A$ & $B$ & $A \& B$ \\
\hline 0 & 0 & 0 \\
\hline 0 & 1 & 0 \\
\hline 1 & 0 & 0 \\
\hline 1 & 1 & 1 \\
\hline
\end{tabular}

Negation is a logical operation which transforms the variable $A$ into the opposite variable $\sim A$. If $A$ is true, then $\sim A$ is false, and vice versa. In this logical paradigm one statement is always true (tertium non datur). Negation is a function of one function $A$ that can be presented by the following truth table 3 .

Table 3. Negation A

\begin{tabular}{|c|c|}
\hline $\mathrm{A}$ & $\sim \mathrm{A}$ \\
\hline 0 & 1 \\
\hline 1 & 0 \\
\hline
\end{tabular}

Let us examine two oxymoronic expressions of the English and Ukrainian languages cruel kindness та солодка мука and infer the oxymoronic implicatures, using logical operations of implication, negation and conjunction. 
First of all, we have to build the algorithm for interring oxymoronic implicatures which consists of five steps. The first step is to define the antecedent, and the consequent of an oxymoron. The second one is to build a formal scheme of the oxymoronic expression. The third stage is to build a logic and pragmatic model of a oxymoronic implicature. The fourth stage is to apply the operation of logical implication and infer an implicature of the oxymoronic expression. The fifth step is to check the correctness of the implicature with the help of a truth table.

I. For the oxymoron cruel kindness, let us define the variable $A$ as one of the diametrically opposed concepts of cruel or kind; in this particular case A will correspond to the concept of cruel, and kind is its negation $(\sim \mathrm{A})$.

Similarly, for the oxymoron, солодка мука the concept of 'солодкий' will be the antecedent $A$, which in its turn has the implicit meaning 'moŭ, що приносить радість, дарує щастя', hence, 'мука' will be a negation of $A(\sim A)$.

II. Since the oxymoron combines two mutually exclusive statements, the formal notation is possible through the conjunction operation $A \& \sim A$. Thus, the formal record of oxymoron cruel kindness and oxymoron солодка мука is represented by the conjunction $\mathrm{A}$ and $\sim \mathrm{A}$ (see Table 4).

Table 4. Formal scheme of the oxymoronic expression cruel kindness та солодка мука

\begin{tabular}{|l|l|l|}
\hline $\mathrm{A}$ & $\sim \mathrm{A}$ & $\mathrm{A} \& \sim \mathrm{A}$ \\
\hline 0 & 1 & 0 \\
\hline 1 & 0 & 0 \\
\hline
\end{tabular}

As we can see from Table 4 above, the oxymoronic statements cruel kindness and солодка мука will logically be equal to zero, i.e. explicitly indicate the obvious falsity of these statements, their implicit meaning will be different, though, combining sweet, pleasant with unpleasant and bitter. Obviously, the oxymoron combines what is supposedly contradictory from the standpoint of formal logic, but it is due to the incompatibility of the parts that a new meaning of the oxymoronic expression is derived. These two examples show the relationship between logic and pragmatics, which lies in the fact, that at first glance everything can be explained by logical laws of thought, but without linguo-pragmatic interpretation it is impossible to understand the true, sometimes hidden meaning of the statement.

III. The next step is to build a logic and pragmatic model of an oxymoronic implicature. The logical and pragmatic model of the oxymoronic implicatures cruel kindness та солодка мука can be presented in the form of conjunction of the antecedent $\boldsymbol{A}$ with the negation of the antecedent $\sim A$ from which we could get the implicit result or the value of the consequent $B:(A \& \sim A) \rightarrow B$.

IV. The fourth stage of our analysis is the application of logical implication to infer oxymoron implicature. The real meaning of the oxymoronic expressions cruel kindness and солодка мука could be set by the implication $A \& \sim A \rightarrow B$, where A\& A (antecedent) is the concept of cruel kindness and солодка мука, and B (consequent) would mean the case when cruelty is necessary for good and мука brings радість.

Thus, the oxymoronic expression could be written using the following operation of formal logic: "if $A \& \sim A$, then $B$ " is also verbally conveyed as follows: "If there is cruel kindness, then there are cases when cruelty is necessary for good" and "If there is солодка мука" then мука can bring насолоду."

$V$. In the fifth stage, we systematize these explanations in the truth table for the implication of oxymoronic statements cruel kindness and солодка мука, where we show what meanings the negation $\sim A$, conjunction $A \& \sim A$ and implication $(A \& \sim A) \rightarrow B$ can take, according to those of variables $A$ and $B$ (see Table. 5).

Table 5. Truth table for oxymoronic implicatures of expressions cruel kindness та солодка мука

\begin{tabular}{|c|c|c|c|c|c|}
\hline & $\mathrm{A}$ & $\sim \mathrm{A}$ & $\mathrm{A} \& \sim \mathrm{A}$ & $\mathrm{B}$ & $(\mathrm{A} \& \sim \mathrm{A}) \rightarrow \mathrm{B}$ \\
\hline & 0 & 1 & 0 & 0 & 1 \\
\hline & 0 & 1 & 0 & 1 & 1 \\
\hline & 1 & 0 & 0 & 0 & 1 \\
\hline & 1 & 0 & 0 & 1 & 1 \\
\hline
\end{tabular}

In Table 5, the variables $A$ and $B$ acquire two values: true (1) or false (0). The functions $\sim A$ and $A \& \sim A$ depend on only one variable $A$ and in the domain of their definition there are two meanings $\{A=0 ; 1\}$. For the implication $(A \& \sim A) \rightarrow B$, which is a function of two variables, there are four possible variants of its definition: 1) $A=0, B=0$; 2) $A=0, B=1$; 3) $A=1$, $B=0$; 4) $A=1, B=1$.

We have already noted that, regardless of the meaning of $A$ (cruelty), the meaning of the expression A\& A (cruelty combined with the denial of this concept - kindness) will always be 
equal to zero, and therefore will be a false statement. This is quite logical, because from a formal point of view, the concept of cruel kindness is wrong. However, because by the laws of mathematical logic any statement follows from a false one, then the statement $(A \& \sim A) \rightarrow B$ will always be true for any meanings of $A$ and $B$. Then, regardless of the meaning of $B$ (the case where cruelty is necessary for good) expression (A\& A) $\rightarrow B$ will be true.

Summarizing the above, we can state that the content of the oxymoronic implicity cruel kindness could be defined as follows: it is from the incompatibility of cruelty and kindness that the real meaning of the oxymoronic statement follows that there is a situation where cruelty is necessary for human good and it must be manifested for true benefit. The oxymoronic expression солодка мука, which according to the truth table is true, indicates that what is given very hard and even makes you suffer, eventually is pleasant, "солодкий", because usually only what is gained in agony, so to say, and suffering, we really appreciate.

Using the same logical and pragmatic algorithm we can analyse other oxymoronic expressions of the English and Ukrainian languages: sweet agony, random order, dark light, definitely maybe, живий труп, дзвінка тиша, солодка гіркота, раби волі. The final aim of this analysis is oxymoronic implicature inferring.

Conclusion. Decoding implicatures is a real challenge which requires the ability of using

\section{References}

1. Brown, Frank Markham, (1990), Boolean Reasoning: The Logic of Boolean Equations, Kluwer Academic Publishers, Norwell, MA, 276.

2. Franke, M., Bergen L. (2020), Theorydriven statistical modeling for semantics and pragmatics: A case study on grammatically generated implicature readings. Language 96 (2), p. 77-96.

3. Goltsova, M. G. (2019), The logic and pragmatic algorithm for the inferring euphemistic implicatures in the Ukrainian and not only linguistic but also logical operations in order to make inferences about speakers' implied intentions.

Oxymoronic constructions are a conscious combination of sharply contrasting words that logically seem to be mutually exclusive, but in fact together convey a new concept, e.g.: pain for pleasure, clearly confused, only choice, amazingly awful, alone together, cruel kindness, living death; живий труп, дзвінка тиша, солодка гіркота, раби волі.

The derivation of the oxymoron implicature helps to decode the metaphorical meaning of the oxymoron expression, since the literal meaning of the oxymoron contains a mystery, and the implication of the implicature is the key to solving it. According to the algorithm proposed in the article, other oxymoronic implicatures of English and Ukrainian languages could be decoded. As we can see, the closely related English and Ukrainian languages have a similar logical and pragmatic algorithm for deriving these implicatures, which testifies to the universality and structural integrity of the phenomenon of implicatures in the languages compared.

The research presented opens the prospects of further scientific research within linguo-pragmatics, which would focus on the construction of logical-pragmatic models and the derivation of other types of implicatures.

English languages. International journal of philology. Vol. 10, № 2, 39-44.

4. Kravchenko, N. K. (2017). Illocution of direct speech acts via conventional implicature and semantic presupposition. Lege artis. Language yesterday, today, tomorrow. The Journal of University of SS Cyril and Methodius in Trnava. Warsaw: De Gruyter Open, Vol. II(1), 128-168.

5. Rett, J. (2020), Manner implicatures and how to spot them. International Review of Pragmatics. Volume 12: Issue 1, P. 44-79.

\section{ЛОГІКО-ПРАГМАТИЧНИЙ АЛГОРИТМ ВИВЕДЕННЯ ОКСИМОРОНИХ ІМПЛІКАТУР В АНГЛІЙСЬКІЙ ТА УКРАЇНСЬКІЙ MOBAX}

М. Г. Гольцова

Анотація. У статті на основі логіко-прагматичного підходу окреслюється механізм виведення імплікатур з стилістичної фрігури оксиморону. Подається визначення стилістичної фрігури оксиморону та оксиморонної імплікатури. Оксиморонну імплікатуру визначено як значення непрямого висловлення, у якому поєднано два чи більше діаметрально протилежних, семантично несумісних понять, із яких утворюється нова, складна, певною мірою суперечлива 
думка, що своїм змістом посідає середнє місце у словесній фрразі.

У науковій розвідиі з точки зору математичної логіки визначено поняття імплікації, кон'юнкції та заперечення. У таблицях істинності для імплікації, кон'юнкції та заперечення показано, яких значень набуває висловлювання $A \rightarrow B$ при заданих значеннях $A$ i B. За допомогою цих логічних операцій зроблено розкодування імплікатур в оксиморонних висловлюваннях 'cruel kindness' та 'солодка мука'.

Було запропоновано авторський логіко-прагматичний алгоритм виведення оксиморонних імплікатур, що складається з п'яти послідовних етапів. У науковій розвідиі при зіставленні логіко-прагматичних моделей оксиморонних імплікатур в англійській та українській мовах було виявлено, що логіко-прагматичні моделі мають ізоморфрне фоормальне вираження 8 порівнюваних мовах.

Ключові слова: оксиморонна імплікатура, логічна операція імплікації, логіко-прагматична модель, антецедент, консеквент, виведення імплікатури. 